\title{
Impact of variety and levels of nitrogen on the growth performance of HYV transplant Aman rice
}

\author{
SK Paul, MS Islam, MAR Sarkar, KR Das ${ }^{1}$, SMM Islam \\ Department of Agronomy, ${ }^{1}$ Department of Entomology, Bangladesh Agricultural University, \\ Mymensingh 2202, Bangladesh
}

\begin{abstract}
An experiment was carried out at the Agronomy Field Laboratory, Bangladesh Agricultural University, Mymensingh during June to December 2012 with a view to finding out the impact of variety and levels of nitrogen on the growth performance of transplant Aman rice. The experiment comprised four varieties viz. BRRI dhan33, BRRI dhan34, BRRI dhan39 and BRRI dhan46, and four levels of nitrogen viz. control (no urea), prilled urea $\left(50 \mathrm{~kg} \mathrm{~N} \mathrm{ha}^{-1}\right)$, one pellet $(0.9 \mathrm{~g})$ of USG/4 hills of two adjacent rows ( $\left.\cong 30 \mathrm{~kg} \mathrm{~N} \mathrm{ha}^{-1}\right)$ was applied at 10 days after transplanting (DAT) and two pellets of USG $(0.9 \mathrm{~g}$ each) one applied at 10 DAT and the another at 45 DAT/4 hills of two adjacent rows $\left(\cong 60 \mathrm{~kg} \mathrm{~N} \mathrm{ha}^{-1}\right)$. The experiment was laid out in a randomized complete block design with three replications. Results of the experiment showed that variety and levels of nitrogen had significant effect on plant height, number of tillers hill ${ }^{-1}$ and leaf area index (LAI) of HYV transplant Aman rice. At 15 and 75 DAT the tallest plant was found in BRRI dhan34 whereas at 30, 45 and 60 DAT the tallest plant was found in BRRI dhan39. BRRI dhan34 produced higher number of tillers hill ${ }^{-1}$ at 75 DAT which was as good as BRRI dhan33 and BRRI dhan46 while BRRI dhan39 produced higher LAI in compare to other varieties at all sampling dates. Two pellets of USG $(0.9 \mathrm{~g}$ each) one applied at 10 DAT and the another at 45 DAT/4 hills of two adjacent rows ( $\cong 60 \mathrm{~kg} \mathrm{~N} \mathrm{ha}^{-1}$ ) can produced tallest plant, higher number tillers hill ${ }^{-1}$ and higher LAI at all dates of sampling. Among the interaction BRRI dhan34 fertilized with two pellets of USG $(0.9 \mathrm{~g}$ each) one applied at $10 \mathrm{DAT}$ and another at $45 \mathrm{DAT} / 4$ hills of two adjacent rows $\left(\cong 60 \mathrm{~kg} \mathrm{~N} \mathrm{ha}^{-1}\right)$ appears as the promising combination in respect of growth performance of HYV transplant Aman rice.
\end{abstract}

Key words: Variety, nitrogen, growth, HYV, transplant aman rice.

Progressive Agriculturists. All rights reserve

*Corresponding Author: skpaull@gmail.com

\section{Introduction}

Rice (Oryza sativa L.) is the most important cereal and staple food crop of Bangladesh. There are three distinct growing seasons of rice according to changes in seasonal conditions as Aus, Aman and Boro. Among them, the largest harvest is obtained from Aman, occurring in November and December accounting for more than half of the area coverage. Aman rice covers the largest area of 5.64 million hectares with a production of 12.70 million tons of rice (BBS, 2011). Depletion of soil fertility has been identified as a major constraint for higher crop yield in Bangladesh. Use of judicial application of fertilizer is an essential component of modern farming with about $50 \%$ of the world crop production (Prodhan, 1992). For rice production, nitrogen is the key nutrient required in the largest quantities while urea is the principal nitrogenous fertilizer. However, $\mathrm{N}$ from urea is subject to considerable losses to the atmosphere and runoff water in the rice ecosystem, especially where urea is broadcast on standing water. On a global level, more than 55 percent of the $\mathrm{N}$ applied through urea fertilizer to irrigated rice is not taken up and eventually liable to loss. In Bangladesh, 
prilled urea (PU) conventionally applied by farmers is very inefficiently used in transplant Aman rice largely because of serious losses (up to $60 \%$ of applied $\mathrm{N}$ ) via $\mathrm{NH}_{3}$ volatilization, denitrification, leaching, and/or runoff. In order to minimize $\mathrm{N}$ loss, especially loss due to denitrification, use of USG in place of prilled urea is very beneficial for transplant Aman rice. USG can be prepared by melt-type processes (pan granulation, falling curtain, and fluid bed) and briquetting (a special type of compaction). Placement of USG can be done efficiently by hand near the center of each four rice hills to a 7-10 cm soil depth. The deepplaced USG-N is well protected from various $\mathrm{N}$ loss mechanisms (except leaching) at the placement sites in soils and the spatial ammonium concentration gradients help to improve its plant availability. Depending on agro climate and $\mathrm{N}$ rates used, in general deep-placed USG can help to provide a saving of urea fertilizer of up to $65 \%$ with an average of $33 \%$ and can help to increase grain yields up to $50 \%$ with an average of $15 \%$ to $20 \%$ over that with the same amount of splitapplied $\mathrm{N}$ as prilled urea. Plant growth is seriously hampered when lower dose of $\mathrm{N}$ is applied which drastically reduces the yield (Khatab et al., 2013). However, excess amount of $\mathrm{N}$-fertilizer also results in lodging of plants, prolonging growing period, delayed in maturity, increased the susceptibility to insect-pest and diseases and ultimately reduces yield (Uddin, 2003). Therefore, optimum dose of $\mathrm{N}$-fertilizer application and its efficient management are necessary to proper growth of rice which is prerequisite for grain yield. Based on the above information, the study was undertaken to investigate impact of levels of nitrogen on the growth performance of HYV transplant Aman rice.

\section{Materials and Methods}

The experiment was conducted at the Agronomy Field laboratory, Bangladesh Agricultural University, Mymensingh during July to December 2012. The experimental site belongs to the Sonatola Soil Series of Old Brahmaputa Floodplain (AEZ 9) having non calcareous dark grey floodplain soil. The land was medium high with sandy loam texture having $\mathrm{pH}$ 5.9-6.5. The experiment consisted of four varieties viz. BRRI dhan33, BRRI dhan34, BRRI dhan39 and BRRI dhan46; and four levels of nitrogen viz. control (no urea), prilled urea $\left(50 \mathrm{~kg} \mathrm{~N} \mathrm{ha}^{-1}\right)$, one pellet $(0.9 \mathrm{~g})$ of USG/4 hills of two adjacent rows $(\cong 30 \mathrm{~kg} \mathrm{~N}$ $\mathrm{ha}^{-1}$ ) was applied at 10 DAT and two pellets of USG $(0.9 \mathrm{~g}$ each) one applied at 10 DAT and the another at $45 \mathrm{DAT} / 4$ hills of two adjacent rows ( $\cong$ $60 \mathrm{~kg} \mathrm{~N} \mathrm{ha}^{-1}$ ). The experiment was laid out in a randomized complete block design with three replications. The size of unit plot was $4.0 \mathrm{~m} \times 2.5 \mathrm{~m}$. Spacing of $1 \mathrm{~m}$ and $0.75 \mathrm{~m}$ were maintained in between the replications and unit plot, respectively. Fertilizers were applied to the plots at the rate of $90,60,40$ and $10 \mathrm{~kg} \mathrm{ha}^{-1}$ of $\mathrm{P}_{2} \mathrm{O}_{5}, \mathrm{~K}_{2} \mathrm{O}, \mathrm{S}$ and $\mathrm{Zn}$ through triple super phosphate, muriate of potash, gypsum and zinc sulphate at the time of final land preparation. Prilled urea was applied at the rate of $50 \mathrm{~kg} \mathrm{~N} \mathrm{ha}^{-1}$ in three installments at 15, 30 and 45 DAT. As per experimental specification USG were placed manually (depth $6-8 \mathrm{~cm}$ ) at the centre of four hills of two adjacent rows at 10 days after transplanting (DAT). In case of twice, USG was placed at 10 DAT and 45 DAT. Five hills were marked by bamboo stick excluding boarder rows to collect data on plant height and tiller number. Five hills were destructed every sampling dates for leaf area index . Data on crop growth parameters viz. plant height, number of tillers hill ${ }^{-1}$ and leaf area index were taken at intervals of 15 days at 15,30 , 45, 60 and 75 DAT. The leaf area was measured by an automatic leaf area meter (Type AAN-7, Hayashi Dam Ko Co., Japan). Leaf area index was calculated as the ratio of total leaf area and total ground area of the sample as described by Hunt (1978).

$$
\mathrm{LAI}=\mathrm{LA} / \mathrm{P}
$$

Where,

$$
\begin{aligned}
& \mathrm{LAI}=\text { Leaf area index } \\
& \mathrm{LA}=\text { Total leaf area of the leaves of all the } \\
& \text { sampled plants }\left(\mathrm{cm}^{2}\right) \\
& \mathrm{P}=\text { Area of the ground surface covered by } \\
& \text { the plant }\left(\mathrm{cm}^{2}\right)
\end{aligned}
$$

The recorded data were statistically analyzed using the "Analysis of Variance" technique and the differences among treatment means were adjudged by Duncan's New Multiple Range Test (Gomez and Gomez, 1984). 


\section{Results and Discussion}

\section{Impact of variety}

Growth parameters viz. plant height, number of tillers hill $^{-1}$ and leaf are area index (LAI) were influenced by variety. Plant height in all the varieties increased progressively with the advancement of time from 15 to 75 DAT. BRRI dhan34 showed superiority in plant height followed by BRRI dhan39, BRRI dhan46 and BRRI dhan33 (Table 1).

Table 1. Effect of varieties on plant height at different day after transplanting

\begin{tabular}{lccccc}
\hline Variety & \multicolumn{5}{c}{ Plant height (cm) } \\
\cline { 2 - 6 } & \multicolumn{5}{c}{ Days after transplanting (DAT) } \\
\cline { 2 - 6 } & 15 & 30 & 45 & 60 & 75 \\
\hline $\begin{array}{l}\text { BRRI } \\
\text { dhan33 }\end{array}$ & $25.01 \mathrm{~d}$ & $44.58 \mathrm{~b}$ & $69.00 \mathrm{c}$ & $93.33 \mathrm{~b}$ & $98.66 \mathrm{~d}$ \\
$\begin{array}{l}\text { BRRI } \\
\text { dhan34 }\end{array}$ & $31.42 \mathrm{a}$ & $50.57 \mathrm{a}$ & $72.37 \mathrm{~b}$ & $86.13 \mathrm{c}$ & $122.60 \mathrm{a}$ \\
$\begin{array}{l}\text { BRRI } \\
\text { dhan39 }\end{array}$ & $29.61 \mathrm{~b}$ & $50.88 \mathrm{a}$ & $74.64 \mathrm{a}$ & $99.47 \mathrm{a}$ & $109.37 \mathrm{~b}$ \\
$\begin{array}{l}\text { BRRI } \\
\text { dhan46 }\end{array}$ & $28.16 \mathrm{c}$ & $45.17 \mathrm{~b}$ & $70.96 \mathrm{~b}$ & $95.06 \mathrm{~b}$ & $105.13 \mathrm{c}$ \\
\hline $\begin{array}{l}\text { CV (\%) } \\
\text { C. }\end{array}$ & 5.41 & 3.38 & 3.49 & 4.05 & 4.14 \\
\hline $\begin{array}{l}\text { Level of } \\
\text { Sig. }\end{array}$ & $* *$ & $* *$ & $* *$ & $* *$ & $* *$ \\
\hline
\end{tabular}

In a column, figures with same letter or without letter do not differ significantly whereas figures with dissimilar letters differ significantly as per DMRT, $* *=$ Significant at $1 \%$ level of probability

Varietal differences regarding plant height might be due to their differences in genetic constitution. Similar results were reported elsewhere (Ray et al., 2015; Kirttania et al. 2013; Tyeb et al., 2013 and BRRI, 1991 and Shamsuddin et al., 1988). Number of total tillers hill ${ }^{-1}$ was significantly influenced by variety at all dates of transplanting (Table 4). The number of tillers hill ${ }^{-1}$ increased in all the varieties from 15 to 60 DAT but it decreased in all the varieties at 75 DAT. The highest number of tillers hill $^{-1}$ was produced by BRRI dhan34 which was as good as BRRI dhan46 and BRRI dhan33 and the lowest one in BRRI dhan39. Jisan et al. (2014) and Kirttania et al. (2013) found variable effect of variety on number of tillers hill ${ }^{-1}$. The variety had significantly effect on leaf area index on 30 DAT and 45 DAT. Both BRRI dhan39 and BRRI dhan 33 showed superiority over BRRI dhan 46 and BRRI dhan34. Leaf area index gradually increased up to
60 DAT in all varieties and then declined thereafter due to leaf abscission and tiller drying (Table 7). Similar trend of LAI was reported by Paul et al. (2013).

\section{Impact of levels of nitrogen}

The plant height was significantly influenced due to application of nitrogen level irrespective growth stages. A trend of significant of increase in the plant height was observed with the increase in the level of nitrogen from control to two pellet (s) of USG/4 hills providing $0-60 \mathrm{~kg} \mathrm{ha}^{-1}$ at all the dates of observation from 15 to 75 DAT (Table 2).

Table 2. Effect of levels of nitrogen on plant height at different days after transplanting

\begin{tabular}{cccccc}
\hline $\begin{array}{c}\text { Nitrogen } \\
\text { level } \\
\left(\mathrm{kg} \mathrm{ha}^{-1}\right)\end{array}$ & \multicolumn{5}{c}{ Plant height (cm) } \\
\cline { 2 - 6 } & 15 & 30 & 45 & 60 & 75 \\
\hline $\mathrm{N}_{0}$ & 28.14 & 47.36 & $69.96 \mathrm{c}$ & $90.08 \mathrm{c}$ & $106.59 \mathrm{c}$ \\
$\mathrm{N}_{1}$ & 28.61 & 47.83 & $72.34 \mathrm{ab}$ & $93.23 \mathrm{~b}$ & $108.03 \mathrm{bc}$ \\
$\mathrm{N}_{2}$ & 28.43 & 47.75 & $71.54 \mathrm{~b}$ & $94.06 \mathrm{~b}$ & $109.77 \mathrm{ab}$ \\
$\mathrm{N}_{3}$ & 29.01 & 48.26 & $73.13 \mathrm{a}$ & $96.61 \mathrm{a}$ & $111.36 \mathrm{a}$ \\
\hline $\mathrm{CV}(\%)$ & 5.41 & 3.38 & 3.49 & 4.05 & 4.14 \\
\hline Level of & & & & & \\
Sig. & $\mathrm{NS}$ & $\mathrm{NS}$ & $* *$ & $* *$ & $* *$ \\
\hline
\end{tabular}

In a column, figures with same letter or without letter do not differ significantly whereas figures with dissimilar letters differ significantly as per DMRT, NS= Not significant, $* *=$ Significant at $1 \%$ level of probability, $\mathrm{N}_{0}=$ Control, $\mathrm{N}_{1}=$ Prilled urea $\left(50 \mathrm{~kg} \mathrm{~N} \mathrm{ha}^{-1}\right), \mathrm{N}_{2}=$ One pellet $(0.9 \mathrm{~g})$ of USG $/ 4$ hills of two adjacent rows [applied at 10 DAT], $\mathrm{N}_{3}=$ Two pellets ( $0.9 \mathrm{~g}$ each) of USG $/ 4$ hills of two adjacent rows [One pellet was applied at $10 \mathrm{DAT}$ and another one at 45 DAT

The highest plant height was observed when the plant was fertilized with to two pellet(s) [0.9g each] of USG/4 hills of two adjacent rows and the lowest plant height was recorded in control plots. Application of nitrogen increased plant height was reported elsewhere (Zannat et al., 2014; Jisan et al., 2014; and Kirtannia et al., 2013). The effect of nitrogen fertilizer application on the number of total tillers hill ${ }^{-1}$ was significantly influenced at all the dates sampling (Table 5). The number of tillers hill $^{-1}$ increased with the increasing levels of nitrogen from control to two pellet(s) [0.9g each] of USG/4 hills of two adjacent rows providing 0 to 60 $\mathrm{kg} \mathrm{ha}^{-1}$ respectively. Similar phenomenon was also 
reported by Kamal et al. (1988). Nitrogen level had significant effect on leaf area index (LAI) at all dates of sampling (Table 8). The LAI increased progressively with increase in the level of nitrogen from control to two pellet (s) $[0.9 \mathrm{~g}$ each $]$ of USG/4 hills of two adjacent rows providing 0 to $60 \mathrm{~kg} \mathrm{ha}^{-1}$ at all the dates of sampling. The LAI increased up to 60 DAT and thereafter declined. Similar finding was also reported by Paul et al., 2014. Ray et al. (2015) also stated that high nitrogen levels $(80 \mathrm{~kg}$ $\mathrm{N} \mathrm{ha}^{-1}$ ) resulted to higher LAI in rice.

\section{Interaction effect}

Plant height was significantly influenced by the interaction of variety and nitrogen level only at 45 and 60 DAT. At 15, 30 and 75 DAT, numerically the tallest plant height of $32.18 \mathrm{~cm}, 52.34 \mathrm{~cm}$ and $123.98 \mathrm{~cm}$ were found in the treatment combinations of $\mathrm{V}_{2} \times \mathrm{N}_{1}, \mathrm{~V}_{2} \times \mathrm{N}_{3}$ and $\mathrm{V}_{2} \times \mathrm{N}_{3}$ and the shortest plant height of $23.93 \mathrm{~cm}, 43.94 \mathrm{~cm}$ and $95.01 \mathrm{~cm}$ were found in $\mathrm{V}_{2} \times \mathrm{N}_{1}, \mathrm{~V}_{2} \times \mathrm{N}_{0}$ and $\mathrm{V}_{1} \times$ $\mathrm{N}_{0}$ respectively (Table 3 ). A regular trend of increased the plant height in the treatment combinations of all the varieties with the increased in the levels of nitrogen. At 45 DAT showing superiority of BRRI dhan 39 and was followed in successive by BRRI dhan34, BRRI dhan 46 and BRRI dhan33. But at 60 DAT the trend of increase in plant height was rather irregular in the treatment combinations of varieties with increase in the levels of nitrogen. BRRI dhan34 showed superiority over the treatment combinations of BRRI dhan39, BRRI dhan46, BRRI dhan33 and nitrogen levels. The interaction effect of variety and levels of nitrogen at 30 DAT on numbers of tillers hill $^{-1}$ was significant (Table 6). A trend of increase in the number of tillers hill ${ }^{-1}$ with the increasing levels of nitrogen was observed in all the varieties. The interaction effect of variety and nitrogen level on LAI was significant on all the dates of sampling. A trend of increase in the value of LAI was observed in each variety with the increasing levels of nitrogen (Table 9).

\section{Relationship between leaf area index (LAI) and grain yield of HYV transplant Aman rice}

Leaf area index (LAI) is an important character responsible for higher yield. Experimental results revealed that grain yield showed significantly positive correlation $\left(\mathrm{R}^{2}=0.7854 * *\right)$ with leaf area index at 75 DAT (Figure 1). This means an increase in leaf area index will result in the corresponding increase in the grain yield of transplant Aman rice. Thus indicate leaf area index might be critical characteristics in yield performance of transplant Aman rice. Similar trend of relationship of LAI and grain yield of transplant Aman rice was reported by Ray et al. (2015).

Table 3. Effect of interaction between variety and levels of nitrogen on plant height at different days after transplanting

\begin{tabular}{|c|c|c|c|c|c|}
\hline \multirow{3}{*}{$\begin{array}{c}\text { Interaction } \\
\text { (Variety } x \\
\text { Nitrogen } \\
\text { level) }\end{array}$} & \multicolumn{5}{|c|}{ Plant height $(\mathrm{cm})$} \\
\hline & \multicolumn{5}{|c|}{ Days after transplanting (DAT } \\
\hline & 15 & 30 & 45 & 60 & 75 \\
\hline $\mathrm{V}_{1} \times \mathrm{N}_{0}$ & 24.91 & 44.23 & $5.41 \mathrm{~g}$ & $6.05 \mathrm{e}$ & SOP1 \\
\hline $\mathrm{V}_{1} \times \mathrm{N}_{1}$ & 24.95 & 44.95 & ef & $d$ & 95.96 \\
\hline $\mathrm{V}_{1} \times \mathrm{N}_{2}$ & 23 & 8 & $f$ & $\mathrm{bc}$ & 1.79 \\
\hline $\mathrm{V}_{1} \times \mathrm{N}_{3}$ & 26.26 & 43.94 & 1.0נה & ת..50a & $101 ., 0$ \\
\hline $\mathrm{V}_{2} \times \mathrm{N}_{0}$ & 31.41 & 4 & 72.4 & 84 & 10 \\
\hline $\mathrm{V}_{2} \times \mathrm{N}_{1}$ & 32.18 & 50.59 & $72.89 \mathrm{bcd}$ & $85.80 \mathrm{e}$ & 123.09 \\
\hline $\mathrm{V}_{2} \times \mathrm{N}_{2}$ & 30.89 & 50.23 & $71.95 \mathrm{c}-\mathrm{f}$ & $85 c r a r a r$ & 12105 \\
\hline $\mathrm{V}_{2} \times \mathrm{N}_{3}$ & 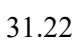 & 52.34 & & & 123.98 \\
\hline$V_{3} x$ & 2 & 1 & 1 & $\mathrm{~b}$ & 107.43 \\
\hline $\mathrm{V}_{3} \times \mathrm{N}_{1}$ & 29.34 & 49.97 & 74.9 & $101.03 \mathrm{a}$ & 109.99 \\
\hline $\mathrm{V}_{3} \times \mathrm{N}_{2}$ & 30.43 & 50.80 & $75.93 \mathrm{ab}$ & $99.11 \mathrm{ab}$ & 109.61 \\
\hline $\mathrm{V}_{3} \times \mathrm{N}_{3}$ & 30.65 & 52.28 & 7746 & 004 & 11046 \\
\hline $\mathrm{V}_{4} \times \mathrm{N}_{0}$ & 3 & & -T & & 10 \\
\hline $\mathrm{V}_{4} \times \mathrm{N}_{1}$ & 27.97 & 45.82 & $71.35 \mathrm{def}$ & $93.88 \mathrm{bc}$ & 103.09 \\
\hline $\mathrm{V}_{4} \times \mathrm{N}_{2}$ & 28.50 & 44.78 & $69.38 \mathrm{ef}$ & $95.57 \mathrm{abc}$ & 106.63 \\
\hline & 27.93 & 44.47 & 71.34def & $99.59 \mathrm{a}$ & 109.12 \\
\hline CV(\%) & 5.41 & 3.38 & 3.49 & 4.05 & 4.14 \\
\hline $\begin{array}{c}\text { Level o } \\
\text { Sig. }\end{array}$ & NS & NS & $n^{2}+2-3$ & Fin & NS \\
\hline
\end{tabular}

In a column, figures with same letter or without letter do not differ significantly whereas figures with dissimilar letters differ significantly as per DMRT, NS= Not significant, *= Significant at $5 \%$ level of probability, $* *=$ Significant at $1 \%$ level of probability, $\mathrm{V}_{1}=$ BRRI dhan $33, \mathrm{~V}_{2}=\mathrm{BRRI}$ dhan34, $\mathrm{V}_{3}=$ BRRI dhan39, $\mathrm{V}_{4}=$ BRRI dhan46, $\mathrm{N}_{0}=$ Control, $\mathrm{N}_{1}=$ Prilled urea $\left(50 \mathrm{~kg} \mathrm{~N} \mathrm{ha}^{-1}\right), \mathrm{N}_{2}=$ One pellet $(0.9 \mathrm{~g})$ of USG $/ 4$ hills of two adjacent rows [applied at $10 \mathrm{DAT}$ ], $\mathrm{N}_{3}=$ Two pellets ( $0.9 \mathrm{~g}$ each) of USG $/ 4$ hills of two adjacent rows [One pellet was applied at 10 DAT and another one at 45 DAT] 


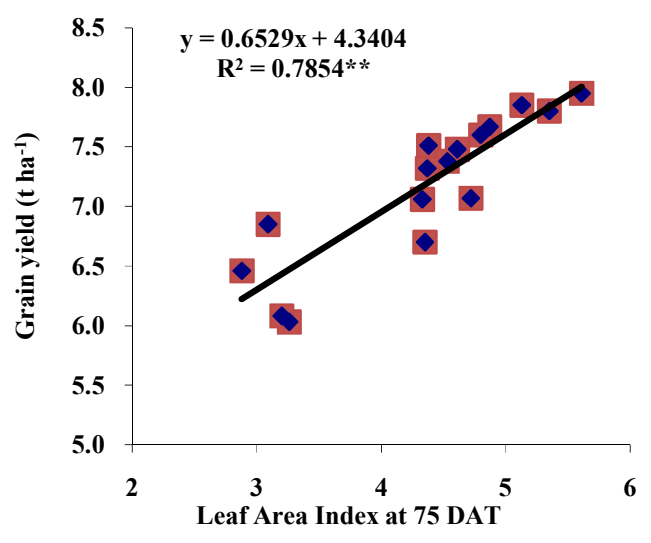

Figure 1. Relationship between leaf area index and grain yield of HYV transplant Aman rice at 75 days after transplanting (DAT)

Table 4. Effect of varieties on number of tillers hill $^{-1}$ at different days after transplanting

\begin{tabular}{|c|c|c|c|c|c|}
\hline \multirow{3}{*}{ Variety } & \multicolumn{5}{|c|}{ Number of tillers hill $^{-1}$} \\
\hline & \multicolumn{5}{|c|}{ Days after transplanting (DAT) } \\
\hline & 15 & 30 & 45 & 60 & 75 \\
\hline $\begin{array}{l}\text { BRRI } \\
\text { dhan33 }\end{array}$ & $4.37 \mathrm{~b}$ & $6.46 \mathrm{~b}$ & $9.00 \mathrm{~b}$ & $11.80 \mathrm{a}$ & $10.90 \mathrm{a}$ \\
\hline $\begin{array}{l}\text { BRRI } \\
\text { dhan34 } \\
\text { BRRI }\end{array}$ & $4.53 \mathrm{ab}$ & $7.31 \mathrm{a}$ & $10.17 \mathrm{a}$ & $12.19 \mathrm{a}$ & $11.17 \mathrm{a}$ \\
\hline $\begin{array}{l}\text { dhan39 } \\
\text { BRRI }\end{array}$ & $4.84 \mathrm{a}$ & $7.67 \mathrm{a}$ & $10.28 \mathrm{a}$ & $10.80 \mathrm{~b}$ & $9.78 \mathrm{~b}$ \\
\hline dhan 46 & $4.62 \mathrm{ab}$ & $7.25 \mathrm{a}$ & $10.72 \mathrm{a}$ & $11.98 \mathrm{a}$ & $10.69 \mathrm{a}$ \\
\hline $\mathrm{CV}(\%)$ & 8.61 & 12.6 & 8.26 & 8.05 & 8.16 \\
\hline $\begin{array}{l}\text { Level of } \\
\text { Sig. }\end{array}$ & ** & ** & ** & ** & ** \\
\hline
\end{tabular}

In a column, figures with same letter or without letter do not differ significantly whereas figures with dissimilar letters differ significantly as per DMRT, $* *=$ Significant at $1 \%$ level of probability

Table 5. Effect of levels of nitrogen on number of tillers hill $^{-1}$ at different days after transplanting

\begin{tabular}{cccccc}
\hline \multirow{2}{*}{$\begin{array}{c}\text { Nitrogen } \\
\text { level }(\mathrm{kg} \\
\left.\text { ha }^{-1}\right)\end{array}$} & \multicolumn{5}{c}{ Number of tillers hill ${ }^{-1}$} \\
\cline { 2 - 6 } & 15 & 30 & 45 & 60 & 75 \\
\hline $\mathrm{N}_{0}$ & $4.21 \mathrm{c}$ & $5.43 \mathrm{c}$ & $8.31 \mathrm{c}$ & 8.53 & $7.05 \mathrm{~d}$ \\
$\mathrm{~N}_{1}$ & $4.50 \mathrm{bc}$ & $7.39 \mathrm{~b}$ & $9.64 \mathrm{~b}$ & 11.52 & $10.81 \mathrm{c}$ \\
$\mathrm{N}_{2}$ & $4.70 \mathrm{ab}$ & $7.27 \mathrm{~b}$ & $10.79 \mathrm{a}$ & 12.73 & $11.97 \mathrm{~b}$ \\
$\mathrm{~N}_{3}$ & $4.96 \mathrm{a}$ & $8.59 \mathrm{a}$ & $11.42 \mathrm{a}$ & 13.99 & $12.72 \mathrm{a}$ \\
\hline $\mathrm{CV}(\%)$ & 8.61 & 12.6 & 8.26 & 8.05 & 8.16 \\
\hline Level of & & & & & \\
Sig. & $* *$ & $* *$ & $* *$ & $\mathrm{NS}$ & $* *$ \\
\hline
\end{tabular}

In a column, figures with same letter or without letter do not differ significantly whereas figures with dissimilar letters differ significantly as per DMRT, NS $=$ Not significant, $* *=$ Significant at $1 \%$ level of probability, $\mathrm{N}_{0}=$ Control, $\mathrm{N}_{1}=$ Prilled urea $\left(50 \mathrm{~kg} \mathrm{~N} \mathrm{ha}^{-1}\right), \mathrm{N}_{2}=$ One pellet $(0.9 \mathrm{~g})$ of USG $/ 4$ hills of two adjacent rows [applied at 10 DAT], $\mathrm{N}_{3}=$ Two pellets $(0.9 \mathrm{~g}$ each $)$ of USG $/ 4$ hills of two adjacent rows [One pellet was applied at 10 DAT and another one at 45 DAT

Table 6. Effect of interaction between variety and levels of nitrogen on the number of tillers hill $^{-1}$ at different days after transplanting

\begin{tabular}{|c|c|c|c|c|c|}
\hline \multirow{3}{*}{$\begin{array}{c}\text { Interaction } \\
\text { (Variety } \mathrm{x} \\
\text { Nitrogen } \\
\text { level) } \\
\end{array}$} & \multicolumn{5}{|c|}{ Number of tillers hill $^{-1}$} \\
\hline & \multicolumn{5}{|c|}{ Days after transplanting (DAT) } \\
\hline & 15 & 30 & 45 & 60 & 75 \\
\hline $\mathrm{V}_{1} \times \mathrm{N}_{0}$ & 4.20 & $4.23 \mathrm{a}$ & 8.06 & 7.76 & 7.33 \\
\hline $\mathrm{V}_{1} \times \mathrm{N}_{1}$ & 4.27 & $7.00 \mathrm{ab}$ & 8.27 & 11.68 & 10.62 \\
\hline $\mathrm{V}_{1} \times \mathrm{N}_{2}$ & 4.39 & $7.00 \mathrm{ab}$ & 9.51 & 13.59 & 12.56 \\
\hline $\mathrm{V}_{1} \times \mathrm{N}_{3}$ & 4.62 & $7.60 \mathrm{ab}$ & 10.17 & 14.16 & 13.11 \\
\hline $\mathrm{V}_{2} \times \mathrm{N}_{0}$ & 4.11 & $5.64 \mathrm{ab}$ & 8.62 & 8.60 & 7.21 \\
\hline $\mathrm{V}_{2} \times \mathrm{N}_{1}$ & 4.48 & $9.60 \mathrm{a}$ & 9.78 & 12.51 & 12.01 \\
\hline $\mathrm{V}_{2} \times \mathrm{N}_{2}$ & 4.62 & $6.60 \mathrm{ab}$ & 10.82 & 13.52 & 12.49 \\
\hline $\mathrm{V}_{2} \times \mathrm{N}_{3}$ & 4.92 & $7.40 \mathrm{ab}$ & 11.45 & 14.12 & 12.99 \\
\hline $\mathrm{V}_{3} \times \mathrm{N}_{0}$ & 4.38 & $7.05 \mathrm{ab}$ & 8.17 & 8.69 & 7.02 \\
\hline $\mathrm{V}_{3} \times \mathrm{N}_{1}$ & 4.73 & $6.95 \mathrm{ab}$ & 9.80 & 10.51 & 9.34 \\
\hline $\mathrm{V}_{3} \times \mathrm{N}_{2}$ & 5.07 & $7.27 \mathrm{ab}$ & 11.25 & 11.12 & 10.66 \\
\hline $\mathrm{V}_{3} \times \mathrm{N}_{3}$ & 5.19 & $9.39 \mathrm{a}$ & 11.88 & 12.89 & 12.09 \\
\hline $\mathrm{V}_{4} \times \mathrm{N}_{0}$ & 4.14 & $4.80 \mathrm{~b}$ & 8.40 & 9.05 & 6.64 \\
\hline $\mathrm{V}_{4} \mathrm{xN}_{1}$ & 4.53 & $6.00 \mathrm{ab}$ & 10.72 & 11.37 & 11.25 \\
\hline $\mathrm{V}_{4} \times \mathrm{N}_{2}$ & 4.70 & $8.20 \mathrm{ab}$ & 11.60 & 12.68 & 12.17 \\
\hline $\mathrm{V}_{4} \times \mathrm{N}_{3}$ & 5.12 & $9.98 \mathrm{a}$ & 12.15 & 14.80 & 12.70 \\
\hline $\mathrm{CV}(\%)$ & 8.61 & 12.6 & 8.26 & 8.05 & 8.16 \\
\hline $\begin{array}{c}\text { Level of } \\
\text { Sig. }\end{array}$ & NS & $* *$ & NS & NS & NS \\
\hline
\end{tabular}

In a column, figures with same letter or without letter do not differ significantly whereas figures with dissimilar letters differ significantly as per DMRT, NS= Not significant, $*=$ Significant at $5 \%$ level of probability, $* *=$ Significant at $1 \%$ level of probability, $\mathrm{V}_{1}=$ BRRI dhan $33, \mathrm{~V}_{2}=\mathrm{BRRI}$ dhan34, $\mathrm{V}_{3}=$ BRRI dhan39, $\mathrm{V}_{4}=$ BRRI dhan $46, \mathrm{~N}_{0}=$ Control, $\mathrm{N}_{1}=$ Prilled urea $\left(50 \mathrm{~kg} \mathrm{~N} \mathrm{ha}^{-1}\right), \mathrm{N}_{2}=$ One pellet $(0.9 \mathrm{~g})$ of USG $/ 4$ hills of two adjacent rows [applied at $10 \mathrm{DAT}$ ], $\mathrm{N}_{3}=$ Two pellets ( $0.9 \mathrm{~g}$ each) of USG $/ 4$ hills of two adjacent rows [One pellet was applied at 10 DAT and another one at 45 DAT] 
Table 7. Effect of varieties on leaf area index at different days after transplanting

\begin{tabular}{lccccc}
\hline \multirow{2}{*}{ Variety } & \multicolumn{5}{c}{ Leaf area index (LAI) } \\
\cline { 2 - 6 } & \multicolumn{5}{c}{ Days after transplanting (DAT) } \\
\cline { 2 - 6 } & 15 & 30 & 45 & 60 & 75 \\
\hline $\begin{array}{l}\text { BRRI } \\
\text { dhan33 }\end{array}$ & $2.02 \mathrm{~b}$ & $4.77 \mathrm{c}$ & $5.55 \mathrm{bc}$ & $6.40 \mathrm{~b}$ & $5.39 \mathrm{~b}$ \\
$\begin{array}{l}\text { BRRI } \\
\text { dhan34 }\end{array}$ & $1.82 \mathrm{c}$ & $4.65 \mathrm{c}$ & $5.38 \mathrm{c}$ & $5.96 \mathrm{c}$ & $5.45 \mathrm{~b}$ \\
$\begin{array}{l}\text { BRRI } \\
\text { dhan39 }\end{array}$ & $2.18 \mathrm{a}$ & $5.48 \mathrm{a}$ & $6.03 \mathrm{a}$ & $6.88 \mathrm{a}$ & $5.85 \mathrm{a}$ \\
$\begin{array}{l}\text { BRRI } \\
\text { dhan46 }\end{array}$ & $2.13 \mathrm{~b}$ & $5.28 \mathrm{~b}$ & $5.85 \mathrm{~b}$ & $6.40 \mathrm{ab}$ & $5.65 \mathrm{ab}$ \\
\hline CV(\%) & 16.93 & 17.42 & 10.42 & 12.82 & 10.01 \\
\hline \multicolumn{1}{c}{$\begin{array}{c}\text { Level of } \\
\text { Sig. }\end{array}$} & $* *$ & $* *$ & $* *$ & $* *$ & $* *$ \\
\hline
\end{tabular}

In a column, figures with same letter or without letter do not differ significantly whereas figures with dissimilar letters differ significantly as per DMRT, $* *=$ Significant at $1 \%$ level of probability

Table 8. Effect of levels of nitrogen on the leaf area index at different days after transplanting

\begin{tabular}{cccccc}
\hline \multirow{2}{*}{$\begin{array}{c}\text { Nitrogen } \\
\text { level } \\
\left(\mathrm{kg} \mathrm{ha}^{-1}\right)\end{array}$} & \multicolumn{5}{c}{ Leaf area index (LAI) } \\
\cline { 2 - 6 } & 15 & 30 & 45 & 60 & 75 \\
\hline $\mathrm{N}_{0}$ & $1.57 \mathrm{~d}$ & $3.68 \mathrm{c}$ & $4.76 \mathrm{c}$ & $5.88 \mathrm{c}$ & $4.34 \mathrm{c}$ \\
$\mathrm{N}_{1}$ & $2.07 \mathrm{c}$ & $4.22 \mathrm{~b}$ & $5.50 \mathrm{~b}$ & $6.40 \mathrm{~b}$ & $5.77 \mathrm{~b}$ \\
$\mathrm{~N}_{2}$ & $2.23 \mathrm{~b}$ & $4.95 \mathrm{~b}$ & $5.83 \mathrm{~b}$ & $6.92 \mathrm{a}$ & $5.87 \mathrm{~b}$ \\
$\mathrm{~N}_{3}$ & $2.38 \mathrm{a}$ & $5.40 \mathrm{a}$ & $6.65 \mathrm{a}$ & $7.17 \mathrm{a}$ & $6.63 \mathrm{a}$ \\
\hline $\mathrm{CV}(\%)$ & 16.93 & 17.42 & 10.42 & 12.82 & 10.01 \\
\hline Level of & & & & & \\
Sig. & $* *$ & $* *$ & $* *$ & $* *$ & $* *$ \\
\hline
\end{tabular}

In a column, figures with same letter or without letter do not differ significantly whereas figures with dissimilar letters differ significantly as per DMRT, NS $=$ Not significant, $* *$ $=$ Significant at $1 \%$ level of probability, $\mathrm{N}_{0}=$ Control, $\mathrm{N}_{1}$ $=$ Prilled urea $\left(50 \mathrm{~kg} \mathrm{~N} \mathrm{ha}^{-1}\right), \mathrm{N}_{2}=$ One pellet $(0.9 \mathrm{~g})$ of USG $/ 4$ hills of two adjacent rows [applied at $10 \mathrm{DAT}$ ], $\mathrm{N}_{3}=$ Two pellets $(0.9 \mathrm{~g}$ each $)$ of USG $/ 4$ hills of two adjacent rows [One pellet was applied at $10 \mathrm{DAT}$ and another one at 45 DAT

\section{Conclusion}

BRRI dhan34 produced tallest plant and higher number of tillers hill ${ }^{-1}$ at 75 DAT while BRRI dhan39 produced higher LAI in compare to other varieties at all dates of sampling. Two pellets of USG $(0.9 \mathrm{~g}$ each) one applied at 10 DAT and the other at $45 \mathrm{DAT} / 4$ hills of two adjacent rows $(\cong 60$ $\mathrm{kg} \mathrm{N} \mathrm{ha}^{-1}$ ) produced the tallest plant, higher number tillers hill $^{-1}$ and higher LAI. It can be concluded that BRRI dhan 34 fertilized with two pellets of USG $(0.9 \mathrm{~g}$ each) one applied at 10 DAT and the another at $45 \mathrm{DAT} / 4$ hills of two adjacent rows ( $\cong$ $60 \mathrm{~kg} \mathrm{~N} \mathrm{ha}^{-1}$ ) appears as the promising combination in respect of growth of HYV transplant Aman rice.

Table 9. Effect of interaction between variety and levels of nitrogen on the leaf area index at different days after transplanting

\begin{tabular}{|c|c|c|c|c|c|}
\hline \multirow{3}{*}{$\begin{array}{c}\text { Interaction } \\
\text { (Variety } x \\
\text { Nitrogen } \\
\text { level) }\end{array}$} & \multicolumn{5}{|c|}{ Leaf Area Index (LAI) } \\
\hline & \multicolumn{5}{|c|}{ Days after transplanting (DAT) } \\
\hline & 15 & 30 & 45 & 60 & 75 \\
\hline $\mathrm{V}_{1} \times \mathrm{N}_{0}$ & 1 & 3 & $\mathrm{~cd}$ & -f & ( \\
\hline $\mathrm{V}_{1} \times \mathrm{N}_{1}$ & 2.14 & $3.23 b c$ & $5.12 \mathrm{bc}$ & $5.51 \mathrm{c}-\mathrm{e}$ & $7.51 b$ \\
\hline $\mathrm{V}_{1} \times \mathrm{N}_{2}$ & 2.08 & $2.75 \mathrm{bc}$ & $.76 b$ & $6.57 b c$ & $7.38 \mathrm{ab}$ \\
\hline $\mathrm{V}_{1} \times \mathrm{N}_{3}$ & 2.45 & $2.74 \mathrm{def}$ & 2 & $6.67 \mathrm{~b}$ & $7.67 \mathrm{c}-\mathrm{f}$ \\
\hline $\mathrm{V}_{2} \times \mathrm{N}_{0}$ & 1.58 & $2.21 \mathrm{f}$ & $3.20 \mathrm{e}$ & $5.20 \mathrm{c}-\mathrm{f}$ & 60 \\
\hline $\mathrm{V}_{2} \times \mathrm{N}_{1}$ & 2.02 & 2.32def & $3.70 \mathrm{de}$ & $5.91 \mathrm{c}-\mathrm{f}$ & $7.06 \mathrm{c}-\mathrm{f}$ \\
\hline $\mathrm{V}_{2} \times \mathrm{N}_{2}$ & 2.15 & 3.04def & $3.51 \mathrm{e}$ & $-f$ & $\mathrm{cc}$ \\
\hline $\mathrm{V}_{2} \times \mathrm{N}_{3}$ & 2.25 & $3.32 \mathrm{ab}$ & $5.15 \mathrm{bc}$ & 5.85 & $7.95 \mathrm{a}$ \\
\hline $\mathrm{V}_{3} \times \mathrm{N}_{0}$ & 1.65 & $2.28 \mathrm{f}$ & $3.24 \mathrm{e}$ & $5.54 \mathrm{c}-\mathrm{f}$ & 0.0 \\
\hline $\mathrm{V}_{3} \times \mathrm{N}_{1}$ & 2.08 & $3.17 \mathrm{bc}$ & $4.40 \mathrm{bc}$ & $5.70 \mathrm{ab}$ & $6.70 \mathrm{c}-\mathrm{e}$ \\
\hline $\mathrm{V}_{3} \times \mathrm{N}_{2}$ & 2.34 & $f$ & de & 6 & t \\
\hline $\mathrm{V}_{3} \times \mathrm{N}_{3}$ & 2.47 & $5.00 \mathrm{a}$ & $5.00 \mathrm{c}$ & $6.43 c-f$ & $7.80 \mathrm{ab}$ \\
\hline $\mathrm{V}_{4} \times \mathrm{N}_{0}$ & 1.8 & 2.6 & 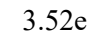 & $5.85 \mathrm{f}$ & $6.85 f$ \\
\hline $\mathrm{V}_{4} \times \mathrm{N}_{1}$ & 3.24 & $2.26 \mathrm{ab}$ & $3.88 \mathrm{ab}$ & $5.17 \mathrm{c}-\mathrm{f}$ & $7.07 \mathrm{c}-\mathrm{f}$ \\
\hline $\mathrm{V}_{4} \times \mathrm{N}_{2}$ & 2.46 & 2.14 & $4.77 \mathrm{e}$ & $5.80 \mathrm{a}-\mathrm{c}$ & $7.60 \mathrm{a}-\mathrm{d}$ \\
\hline $\mathrm{V}_{4} \times \mathrm{N}_{3}$ & 2.64 & 2.90 & $4 \mathrm{c}$ & $5 \mathrm{a}$ & $35 \mathrm{~b}$ \\
\hline $\mathrm{CV}(\%)$ & 18.93 & 17.42 & 10.42 & 12.82 & 10.01 \\
\hline $\begin{array}{l}\text { Leve } \\
\text { Sig }\end{array}$ & NS & F* & $* *$ & $* *$ & $* *$ \\
\hline
\end{tabular}

In a column, figures with same letter or without letter do not differ significantly whereas figures with dissimilar letters differ significantly as per DMRT, NS= Not significant, $* *=$ Significant at $1 \%$ level of probability, $\mathrm{V}_{1}=$ BRRI dhan33, $\mathrm{V}_{2}$ BRRI dhan34, $\mathrm{V}_{3}=$ BRRI dhan $39, \mathrm{~V}_{4}=$ BRRI dhan 46 , $\mathrm{N}_{0}=$ Control, $\mathrm{N}_{1}$ = Prilled urea $\left(50 \mathrm{~kg} \mathrm{~N}^{-1}\right), \mathrm{N}_{2}=$ One pellet $(0.9 \mathrm{~g})$ of USG $/ 4$ hills of two adjacent rows [applied at $10 \mathrm{DAT}$ ], $\mathrm{N}_{3}=$ Two pellets $(0.9 \mathrm{~g}$ each $)$ of USG $/ 4$ hills of two adjacent rows [One pellet was applied at $10 \mathrm{DAT}$ and another one at $45 \mathrm{DAT}$

\section{References}

BBS (Bangladesh Bureau of Statistics) (2011). Statistical Year Book of Bangladesh. Stat. 
Div., Minis. Plan., Govt. People's Republic of Bangladesh, Dhaka. pp.136-140.

Gomez KA, Gomez AA (1984). Statistical Procedures for Agricultural Research. Intl. Rice Res. Inst., John Wiley and Sons. New York, Chickester, Brisbane, Toronto, Singapore, p. 680.

Hunt R (1978). The fitted curve in plant growth studies: Math and plant physiology (Eds. Rose, D.A. and Edwards, DAC). Acad. Press, London. pp. 283-298.

Jisan MT, Paul SK, Salim M (2014). Yield performance of some transplant aman rice varieties as influenced by different levels of nitrogen. J. Bangladesh Agril. Univ., 12 (2): 321-324.

Kamal AMA, Islam MR, Chowdhury BLD (1999). Growth performance, protein content and nutrient uptake by modern varieties of rice under irrigation condition in Bangladesh. Thai J. Agril. Sci., 32(1): 105-110.

Khatab KA, Osman EAM, EL-Masry AA (2013). Rice productivity and its inner quality as affected by anhydrous ammonia rates with foliar application of organic acids. Adv. Appl. Sci. Res., 4:165-173.

Kirttani, B, Sarkar MAR, Paul SK, Islam MS (2013). Morpho-physiological attributes of transplant Aman rice as influenced by variety, age of tiller seedlings and nitrogen management. J. Agrofor. Environ., 7 (2):149154.

Paul SK, Rahman KS, Sarkar MAR (2013). Physiological attributes of transplant Aman rice (cv. BRRI dhan52) as affected by tiller seedlings and urea super granules. Progress. Agric., 24 (1 \& 2):17-27.

Paul SK, Islam SMM, Sarkar MAR, Alam A, Zaman F (2014). Physiological parameters of transplant Aman rice (cv. BRRI dhan49) as influenced by weeding regime and integrated nutrient management. J. Agrofor. Environ., 8 (2): 121-125.

Pradhan SB (1992). "Status of fertilizer use in developing countries of Asia and the pacific region": Proc. Regi. FADINAP seminar, Chiang Mai, Thailand. pp. 37-47.

Ray S, Sarkar MAR, Paul SK, Islam AKMM. Yeasmin S ( 2015). Variation of growth, yield and protein content of transplant Aman rice by three agronomic practices. Agricultural and Biological Sciences Journal, 1 (4):167-176.

Shamsuddin AM, Islam MA, Hossain A (1988). Comparative study on the yield and agronomic characters of nine cultivars of Aus rice. Bangladesh; Agril. Sci., 15(1): 121-124.

Tyeb A, Samad MA, Paul SK (2013). Growth of transplanted Aman rice as affected by variety and spacing. Bangladesh Journal of Environmental Science, 24: 103-108.

Uddin MH (2003). Effect of plant spacing and nitrogen levels on yield of transplanted Aman rice cv. BR39. MS Thesis, Dept. Agron. Bangladesh Agril. Univ., Mymensingh. p.1644.

Zannat ST, Paul SK, Salam MA (2014). Effect of weeding regime and nitrogen management on the performance of transplant aromatic Aman rice (cv. Binadhan-9). Bangladesh J. Seed Sci. \& Tech., 18 (1 \& 2):29-34. 